\title{
Kapitalizmin Şafağında: Kent, Polis ve Güvenlik*
}

*

\author{
Erol Subaşi \\ Recep Tayyip Erdoğan Üniversitesi
}

Öz

Bu çalışma kent ve güvenlik arasındaki bağlantıyı polis kavramı üzerinden incelemektedir. Polis ile kent arasındaki sosyo-tarihsel ilişki bugün unutulmuş ve polis kavramının anlam yelpazesi daralmıştır. Polis, bugün işlevi ya suçluları yakalamak ve suçu önlemek olan bir meslek-kuruma indirgenmekte; ya da hâkim sinıfların tabi sinıfların siyasallaşmasını baskıladığı bir zor aygıtı olarak görülmektedir. Her iki yaklaşım da devlet erkinin bir formu olarak polis erkinin tarihsel seyir içinde üstlendiği daha geniş sosyo-politik işlevleri yakalamaktan uzaktır. Bu eleştiriden hareketle bu çalışmanın temel argümanına göre polis erki kent güvenliğini, salt suçluları yakalayarak, suçu önleyerek ya da siyasal toplumsallaşmayı bastırarak değil; özgül sosyo-politik projeler ile uyumlu bir şekilde kente ait belirli normları, kültürel referansları, kimlikleri ve davranış kalıplarını imal ederek sağlamaktadır. Bu sav, tarihsel bağlamda, feodalizmden kapitalizme geçiş sorunsalı çerçevesinde tartışılacaktır. Ayrıca çalışma, bu temel argümanla bağlantılı olarak dört yan argüman ileri sürmektedir. Birincisine göre, kent ve polis arasındaki tarihsel ve etimolojik bağlantı polisin daralan anlamına rağmen bugün de varlı̆̆ın korumaktadır. İkincisi, tarihsel seyri içinde düzen ve toplumsal düzen kavramlarındaki değişikliklere koşut olarak polis erkinin işlevi değişmiştir. Üçüncüsü, polis erki tarihsel süreç içinde burjuva sivil toplumun değerlerinin üretilmesinde kilit bir rol üstlenmiştir. Dördüncüsü, feodalizmden kapitalizme geçiş döneminde polis erki mülksüz yığınların ücretli emeğe dönüşümünde nazım rol oynamıştır.

Anahtar Kelimeler: Kent, polis, güvenlik, kapitalizm, toplumsal düzen

\footnotetext{
* Bu çalışma, 2214-A 2014 yılı 1. Dönem TÜBİTAK Doktora Sırası Yurtdışı Burs Programı kapsamında 2014-2015 akademik yılı içinde İngiltere Londra Brunel Üniversitesi'nde yapmış olduğum doktora çalışmaları sonucu ortaya çıkmıştır. Çalışmanın Adam Smith ile ilgili olan bölümünün bir kısmı Çukurova Üniversitesi ev sahipliğinde, 5 Kasım 2016 tarihinde gerçekleşen Siyasi İlimler Türk Derneği XIV. Lisansüstü Konferansı'nda bildiri olarak sunulmuştur.
} 


\title{
At the Down of Capitalism: City, Police and Security
}

$*$

\author{
Erol Subaşi \\ Recep Tayyip Erdoğan University
}

\begin{abstract}
This paper examines the connection between the concept of city and security through the concept of police. The socio-historical relation between police and city today has been forgotten and the meaning of the police concept has narrowed. The police are today either being reduced to a profession-institution whose function is to catch criminals and prevent crimes; or are seen as a repressive apparatus with which dominant classes repress the politicization of subordinate classes. Both approaches are far from capturing the broader socio-political functions that police power as a form of state power have performed in the historical process. Based on this critique, the main argument of this study is that police power does not provide the security of the city just by catching criminals, preventing crimes or repressing the social politicization; but in line with specific socio-political projects, it does so by fabricating specific urban norms, cultural references, identities and behavioural patterns. In this study, this claim will be discussed within the problematic of transition from feudalism to capitalism. Furthermore, in conjunction with the main argument, the study puts forward four interrelated supporting arguments. First, despite the police's narrowed meaning, the historical and etymological connection between city and the police persists. Second, parallel to the changing meaning of order and social order, the function of the police power has been altered. Third, the police power has assumed a key role in fabrication of bourgeois civil society's values. Fourth, during the transition from feudalism to capitalism, the police power has played a regulatory role in transforming the dispossessed masses into wage labour.
\end{abstract}

Keywords: City, police, security, capitalism, social order 


\section{Giriş}

Kent ve güvenlik arasındaki ilişki en iyi nasıl anlaşılabilir? Muhtemelen polis kavramı ile. Bu, tarihsel ve etimolojik olarak böyledir; zira bugün kullandığımız polis kelimesi doğrudan doğruya Antik Yunan kent-devleti polis'ten türemiştir (Chapman, 1970, s. 11). Bu aynı zamanda sosyo-politik olarak da böyledir; çünkü polisin işlevi kapitalizmin doğum sancılarının yaşandığı bir dönemde kırdan kente göç etmek zorunda kalarak "özgürleşen" ve yoksullaşan kitlelerin cinayet, hırsızlık, gasp, kumar, fahişelik, dilencilik, sarhoşluk ve aylaklık gibi zararlı ve "üretken" olmayan davranış kalıplarını ortadan kaldırma çabası ile şekillenmiştir (Marx, 2011; Neocleous, 2000). Bu bakımdan kent ve güvenliği ile ilgili herhangi bir çalışma polis erkini göz önünde bulundurmalıdır.

Oysa, günümüzde polis ile kent arasındaki bağlantı silikleşmiştir. Bunun nedeni ana akım polis çalışmalarının biri indirgemeci, diğeri araçsalcı iki aks etrafında şekillenmiş olmasıdır (Reiner, 2000, ss. 15-16). Liberal-kurumsalcı olarak adlandırılabilecek birinci bakış açısına göre polis erki bir kuruma-mesleğe indirgenmiş ve işlevi suçu önlemek ve suçluyu yakalamak ile sınırlandırılmıştır. Bu yaklaşımda, polis'in hem devlet erki ile olan organik ilişkisi, hem de kent- ve dolaylı olarak üretimin toplumsal ilişkileri- ile olan ilişkisi görmezden gelinmektedir. Polis teknik-bürokratik bir birim olarak anlaşılmaktadır. Ortodoks-Marksist araçsalcı ikinci yaklaşıma göre polis, hâkim sınıfların işçi sınıfı hareketliliğini zapt-u rapt altına almak için kullandıkları basit bir enstrüman olarak görülmüştür. Böylece polis, kabaca bir baskı-zor aygıtına indirgenmiştir. Her iki yaklaşım da polisin düzeni imal edici, sosyo-politik işlevini görmezden gelmiştir.

$\mathrm{Bu}$ çalışma, yukarıdaki her iki yaklaşımdan farklı olarak Neoclous (2000)'u izleyerek polis erkini devlet erkinin bir formu olarak salt zorlayıcı değil, aynı zamanda üretken bir güç olarak ele almayı önermektedir. Aşağıda bu yaklaşımın geçerliliği tarihsel örnekleriyle tanıtlanmaya çalışılmaktadır. Buna göre polis erki kent güvenliğini suçluları yakalayarak ya da siyasal toplumsallaşmayı bastırarak değil; daha ziyade özgül bir sosyo-politik çerçeveyi oluşturabilmek için belirli davranış kalıplarını üreterek sağlar. Bu bağlamda, polis erki salt suçluları yakalamaz; neyin suç olduğuna dair genel kanıları üretir, belirli davranış kalıplarını kurumsal-formel olarak ya da bireysel-enformel şekillerde kriminalize eder, yoksulluğun yönetiminde başat bir rol oynar ve bir kamusal alan olarak kentlerdeki toplumsal hareketlere yönelik mü- 
dahaleleri belirli toplumsal siyasallaşma biçimlerini güvenlikleştirir. Bu anlamda bu çalışma, genişletilmiş bir polis kavramının kent güvenliğinin anlaşılmasında önemli teorik imkânlar sunduğunu öne sürmektedir.

Bu temel argüman ışığında bu çalışma, polis erkini yeniden tarihselleştirerek kent ve polis arasındaki bağlantıları hatırlatma ve polis kavramının anlamını geçmişte olduğu gibi genişleterek onu yeniden siyasallaştırma stratejisi üzerine kuruludur. $\mathrm{Bu}$ amaç doğrultusunda çalışma dört ana bölümden oluşmaktadır. İlk bölümde kısaca polis ve polis arasındaki etimolojik ve tarihsel bağ, Antik Yunan'dan Roma'ya; oradan Viktorya Dönemi Britanyası'na uzanacak şekilde gözler önüne serilmektedir. İkinci bölümde polisin değişen rolü 15. yüzyıldan 18. ve 19. yüzyıllara doğru tarihsel bir seyir içinde ortaya konacaktır. Üçüncü bölümde modern polisin izleri sürülerek "yeni polis" kurumunun "yeniliği" mercek altına alınacaktır. Dördüncü ve son bölümde iki önemli liberal düşünürün Patrick Colquhoun ve Adam Smith'in “efendisizler", kent güvenliği ve ücretli emek etrafında oluşturdukları polis projesi masaya yatırılacaktır. Sonuç bölümünde bu tarihsel gelişmeler ve onların yorumlarıyla ilgili tarihselci teorik bağlamın günümüz ile nasıl ilişkilendirilebileceğine dair bazı genel önerilerde bulunulmaktadır.

\section{Tarihsel ve Etimolojik Bağ: Polis ve Polis}

Polis kavramı Antik Yunanca polis [kent] kelimesi ile doğrudan bağlantılıdır. Bu bağlantı bugün olduğu gibi modern polis teşkilatının ortaya çıtığı 19. yüzyılda da bilinmekteydi. Bu bakımdan polis fikri ile kentleşme arasında doğrudan bir ilişki olduğu söylenebilir. Tilly (1992, s. 49)'e göre MS 1000 y1lından sonra Avrupa'da kentsel büyüme beş safhaya ayrılabilir: 1350 civarı bir artış, 1350 ile 1500 yılları arasında düzensiz bir dalgalanma, 17. yüzyılda yavaşlama ve son olarak 1750 sonrasında müthiş bir ivme. Feodalizmin aşamalı çözülüşü özellikle 18. yüzyılda kent popülasyonunda çarpıcı bir artışa neden olmuştur. Kent sakinlerinin sayısındaki bu yükseliş kademeli olarak toplumsal hiyerarşinin geleneksel yapısının bozulmasına ve kentlerde düzensizliklerin baş göstermesine yol açmıştır. Kentler o tarihlerden itibaren dilenciler, baldırı çıplaklar, serseriler, kumarbazlar, sarhoşlar, fahişeler olmak üzere her türden "efendisiz" ile dolmuş ve kentlerde güvensizlik hissi alabildiğince artmıştır. Dolayısıyla polis erkinin bir boyutunu "kentlerdeki güvensizlik ve düzensizlik" oluşturur. O halde, "polis sorunu aynı zamanda kent sorunudur"(Rigakos, McMullan, Johnson, \& Özcan, 2009, s. 3). Bununla birlikte, polis projesi yalnızca artan suç oranları ile ilgili olmamıştır; daha çok 
kentlerde kamu düzenini güvence altına alabilmek için yeni toplumsal davranış kalıplarının oluşturulması ile de ilgili olmuştur. Demek ki polis ilk olarak bir "kent projesidir" (Rigakos vd., 2009, s. 4).

Dubber (2005) polis erkinin Antik Yunandaki patriyarkal köklerini başarılı bir şekilde gözler önüne serer. Buna göre polis, oikonomia olarak "hanehalkı yönetimidir". Bu yönetim, özgün bir sanattır: "tüm ailenin ortak iyiliği için evi yönetme" sanatıdır. Bu tür bir şecere dökümü oikonomia ile günümüz ekonomi kavramları arasındaki ilişkiyi gözler önüne serer. Ekonomi ya da Oikonomi kelimesi oikos, ev ve nomos, yasadan türemiştir. Tüm ailenin ortak iyiliği için evin meşru ve bilgece yönetimi anlamına gelmektedir. Daha sonra kavram, büyük bir aile olarak görülebilecek devlet yönetimini de kapsayacak şekilde genişledi (Dubber, 2005, s. 48). Dubber, polisin yalnızca insanları değil şeyleri de yönetmek anlamına geldiğini belirtir. O halde polis erki suçluları yakalamak ve ceza hukukunu uygulamaktan öte hanenin ve toplumun maddi refahı olarak da anlaşılabilir. Polis erki, mikro hane halkını yönetmekten makro bir düzeyde devletin sivil toplumu yönetme biçimine dönüşmüştür.

Polis kavramı ayrica policy [siyasa] ve social policy [sosyal politika] gibi kavramlarla yakından ilişkilidir. Romalılar, Yunanca polis kelimesinden türemiş olan politeia kelimesini alıp onu Latinceleştirerek politia haline getirmişlerdi. İngilizce policy ve politics kelimeleri bu kökten gelmektedir. Politia terimi "kentin sakinlerinin bekası ve refahı ile ilgili tüm meseleleri kapsar. 'Kenti yönetme sanatı' nosyonunun tümünü kendi içinde ihtiva eder"(Chapman, 1970, ss. 11-12). Polis erkinin Roma İmparatorluğu döneminde devlet otoritesinin kalbinde bulunduğu söylenebilir. Roma İmparatorluğu'nda bir idari birim olarak praefectus urbi, kent valisi, polis erkini kullanmaktan ve polis gücünü kontrol etmekten sorumludur. Valinin otoritesinde bulunan alan o denli kapsamlıdır ki " yangın riskleri, kamu binaları, dini görenekler, özel ve kamu toplantıları, fahişe aktiviteleri, dilenciler ve yabancılar ve genel olarak nüfusun sağlık, emniyet ve ahlakını muhafaza eder" (Chapman, 1970, s. 13).

Roma İmparatorluğu'nun çöküşü ile birlikte birçok benzer idari-hukukipolitik kavram gibi polis de bir yönetim kipi olarak unutuldu. Ancak geç 15. yüzyılda Fransız Burgundian dilinde polis kelimesi yeniden ortaya çıtı. Kısa süre içerisinde, Almanya, İspanya ve İtalya gibi ülkelere yayıldı. O dönemde polisin, tıpkı Yunan ve Roma döneminde olduğu gibi idare ile ilgili olarak geniş şekilde çağırışımları vardı (Raeff, 1983, s. 5). Daha sonra 
ancak 1776'da Yunancadan İngilizceye doğrudan çeviri sonrası politeia bağımsız olarak ya policy ya da police olarak "yönetim formu... kenti tertip etmek düzenlemek" anlamında kullanılmaya başlandı (Neocleous, 2000, s. 11). O günden bu yana polis, daha dar ve belirli bir anlam kazadı: suçu kontrol etmek ve kanun ve düzeni sağlamak.

Viktorya Dönemi'nde doruğa ulaşan endüstrileşme kentlerin maddi ve ahlaki gelişimi ile ilgili olarak yeni duyarlılıklar ve korkular yarattı. Kente gelenlerin kayıtlarının tutulamaması ve bu durumdan kaynaklanan anonimlik önemli bir endişe kaynağı haline geldi. Yine de bu dönemde kentler, yükselen medeniyetin, maddi ve manevi üretimin kalbi olarak görülüyordu. $\mathrm{Bu}$ nedenle toplumsal düzenin, refahı ve üretimi teşvik edebilecek şekilde imal edilmesi gerekiyordu. Bu açıdan "polis, 18. yüzyılın endüstriyel-öncesi dünyası ile endüstriyel kapitalizm üzerine bina edilen Viktorya Dönemi bürokratik devleti arasında, geçiş döneminde, kentlileşen bir toplumun ihtiyaçları doğrultusunda ortaya çıkan düzen talebine karşı verilmiş bir cevapt" (P. T. Smith, 1985, ss. 4-5). Kentleşme oranlarına paralel olarak hijyen ve sağlık sorunlarında da bir artış gözleniyordu. Bu bakımdan polisin temel görevlerinden biri kentlerin hijyenini sağlamak olmuştur. Dahası, medikal polis, veba gibi salgın hastalıklarda kontrol mekanizmalarının ve karantina koşullarının oluşturulmasında kilit rol oynamıştır (Raeff, 1983, ss. 120-121). Bir sonraki bölümde ele alınacağı gibi polis kavramı tarihsel seyir içinde birtakım dönüşümlerden geçti.

\section{Polis'in Değişen Rolü}

Neocleous (2000, s. 5) polis tarihinin üç aşamaya ayrılabileceğini ifade eder. İlk iki aşama Otuz Yıl Savaşları ile (1618-1648) birbirinden ayrılabilirken üçüncü aşama 18. yüzyılda başlayarak 19. yüzyılda önemli değişikliklerle sürdü. Polislik faaliyeti özellikle son iki aşama boyunca bir dönüşümden geçerek basitçe toplumsal düzenin yeniden üretimi ya da sürdürülmesi değil imal edilmesi ${ }^{1}$ olarak varlığını korudu. Bu aşamalar ayrıca devletleşme süreci ile uyumlu bir şekilde sırasıyla erken modern, mutlakiyetçi, ve temsiliyetçi devlet formları ile paralellik gösterir.

Eğer kavramın Antik Yunan ve Roma Dönemi köklerini bir kenara bırakırsak çağdaş polis kavramsallaştırmasına yakın bir anlamın 15. yüzyılda

\footnotetext{
1 İmal etmeyi Neocleous (2000)'un bilinçli bir şekilde tercih ettiği fabrication kelimesini karşılamak için kullanıyorum. Bu ifade, makalenin temel argümanı ile bağlantılı bir şekilde polis erkinin üretken niteliğinin altın çizmektedir.
} 
Fransız-burgundian dilinde policie olarak ortaya çıktığı söylenebilir. Bu dönemde polislik faaliyeti adhoc, tepkisel ve cevap niteliğinde eylemlerden oluşmaktaydı (Neocleous, 2000, ss. 5-6). Bu polislik faaliyeti toplumsal hiyerarşinin geleneksel yapısı ile uyum içindeydi. Polislik faaliyetinin temel mantığ suçluları yakalamak ve ibret-i alem için cezalandırmaktı. Bu çeşit bir polislik faaliyeti aynı zamanda değişmez, ebedi ve ilahi olarak algılanan dönemin düzen anlayışı ile de bağdaşır vaziyette idi. Tabiat, gezegenler sistemi ve toplumsal hiyerarşi sistemleri değişmez olarak görülmekteydi (Neocleous, 2000, s. 6). Benzer şekilde, zaman da- düzen kavramının önemli bir bileşeni olarakdairesel olarak kavranmakta dolayısıyla her şeyin sürekli olarak ilk haline geri dönmekte olduğuna inanılmaktaydı. Bu zaman-mekân tahayyülü şeyleri ve insanları ön-verili hiyerarşik konumlarında tutmak anlamına gelen düzen fikrinin temelini oluşturmaktadır. Buna uygun olarak polislik faaliyeti, suçluları yakalayıp cezalandırarak şeylerin ve insanların toplumsal hiyerarşi içindeki konumlarını güvence altına alma odaklıydı. Bu nedenle polislik suçluları yakalamak ve belirli eylemleri cezalandırmaktan öte bir anlam taşımamaktaydı. Polisin temel görevi her şeyi olduğu gibi, yerli yerinde tutmaktı. Bu dönemde polislik feodal toplumsal ilişkilerin yeniden ve yeniden üretilmesinden sorumluydu (Neocleous, 2000, s. 6).

Polis tarihinin ikinci aşamasında 17. yüzyıl dolaylarında düzen fikrinin kendisi değişmeye ve dönüşmeye başladı. "Yeni dünyanın" keşfi, Reform, Rönesans, Kopernik-Galileo-Newton Devrimi- daha sonra Aydınlanma ve kapitalist ilişkilerin tedrici gelişimi düzen fikrinin değişmesinin zeminini hazırladı. Göksel ve karasal hareket kanunlarının keşfi (Raeff, 1983, s. 26) de değişmez bir şey olarak düzen fikrinden hareket halinde bir evren ve düzen fikrine geçişi kolaylaştırd. Matematiksel, geometrik ve mekanik modellerden hareketle rasyonel akıl yürütmenin toplumsal fenomeni açıklayabileceği düşünülmeye başlandı. Hobbes (1996)'ta bu çabanın harika bir örneği görülebilir. Hobbes mekaniği ve geometriyi kullanarak toplumsal düzeni ve toplumsal yaşamı açıklayabileceğini düşündü. Düzen ve toplumsal düzen fikri yavaş yavaş sekülerleşti ve insan-yapımı, sürekli dönüşüm geçiren bir şey olarak algılanmaya başlandı. Bu dönemin bir tanığı olarak Hobbes toplumsal düzeni oluşturma ve koruma sorumluluk ve ayrıcalığını ilahi güçlere değil egemene verdi. Uhrevi, kutsal ve göksel bir toplumsal düzen tahayyülünden kademeli olarak dünyevi, değişen ve kusurlu bir düzen anlayışına geçildi. Bu yaklaşım çizgisel zaman anlayışı ve "ilerleme fikri" ile birlikte hâkim olmaya başladı. Raeff (1983, ss. 38-39)'in ifade ettiği gibi eğer toplumsal düzen insan yapımı ve sürekli değişen bir karakterde 
ise politik otoritenin toplumsal düzenin imalatına şu ya da bu şekilde dahil olmasından başka çaresi yoktu. İşte bu yeni bakış açısının gereği olarak gündelik yaşam devlet erkinin bir formu olarak polis erki aracılığıyla yazılı hale getirildi, sistematikleştirildi ve rutinleştirildi.

Polis tarihinin bu ikinci aşamasında polis erki burjuva toplumsal düzenin imal edilmesinde özel bir güç olarak algılanmaya başlandı. Örneğin constable [polis memuru], watchman [bekçi], yeomanry [çiftçilerden oluşmuş gönüllü süvari alayı] gibi kategoriler bilinirken police [polis] Aralık 1714'te, Kraliçe Anne'in “İskoçya için Polis Heyeti”ni seçmesi ile ilk kez resmi olarak kullanıldı (Neocleous, 2000, ss. 9-10). Bu polis gücü ile “ 6 asilzade ile 4 beyefendi" "ülkenin genel idaresinden" sorumlu hale getirildi (Dubber, 2005, s. 63). Bu bilgiler ışığında İskoçlar'ın o tarihlerde polisi aşağı yukarı modern bir çerçeve içinden düşünmeye başladıklarını söylemek mümkündür. Aynı şekilde, İskoç Aydınlanmacıları ve özellikle Adam Smith'in polis hakkında yazmak zorunda hissetmesi, polis fikrinin o dönemde oldukça popüler hale geldiğini göstermektedir. ${ }^{2}$

Polis tarihinin üçüncü aşamasında, 1770'ler civarı, polis neredeyse bir asırdan bu yana kıta Avrupa'sı için politik ve hukuki düşüncenin ve pratiğin ana konularından biri haline gelmiştir. Özellikle, Fransa ve Almanya'da bir "polis bilimi" oluşturulmuş ve 15. yüzyıldan o döneme değin polis yasaları, düzenlemeleri, talimatnameleri, polis mahkemeleri ve nihayetinde polis memurları kıta Avrupası devletlerinde ve neredeyse tüm kentlerde ortaya çıkmıştır (Dubber, 2005, s. 63). Benzer şekilde, Marc Raeff (1983) geç 16. yüzyıldan itibaren 17. ve 18. yüzyıl boyunca Alman ve Rus toplumlarının polizeiordnungens $^{3}$ [polis talimatnameleri] ile PolizeiStaat ${ }^{4}$ [Düzenli Polis Devletleri] yaratmak için Alman ve Rus toplumlarının nasıl dönüştürüldüğünü başarılı bir şekilde gözler önüne serer. Buradaki hayati nokta 16. yüzyıldan itibaren toplumsal düzen algısındaki değişime koşut olarak polis erkinin yalnızca zorlayıcı ve baskılayıcı değil aynı zamanda burjuva düzenini yaratmada üretken ve yaratıcı bir güç olarak ortaya çıkmış

\footnotetext{
${ }^{2}$ Adam Smith'in polis ile ilgili görüşleri aşağıda ele alınacaktır.

${ }^{3}$ Raeff (1983, s. 52) Weber'i izleyerek şunu iddia eder: "yasalar kapsayıcı bir şekilde yazılı hale getirilene dek gerçek bir bürokrasi mümkün değildi - Batı'da ve merkez Avrupa'da ancak on sekizinci yüzyılın ikinci yarısında, o da önceki polis talimatnamelerinin oluşturduğu zemin üzerinden [yapıldı]."

${ }^{4}$ Günümüzde özellikle Nazi Almanyası ve Stalin dönemi Sovyetleri ile özdeşleştirilen Polis Devleti ifadesi ile Almanların kullandığı biçimiyle Polizeistaat ifadesi karıştırılmamalı. Birincisi baskıcı "totaliter" rejimlere gönderme yaparken ikincisi 17. ve 18. yüzyıllarda Prusya ve Avusturya' da ekonomik sosyal ve askeri kaynakların devletin ve toplumun refahı için seferber edildiği refah, düzen ve güvenliğin el ele gittiği bir devlet organizasyonu biçimi olarak ortaya çıkmaktadır.
} 
olmasıdır. Devlet erkinin bir parçası olarak polis erki burjuva toplumunu daha üretken, gayretkeş, rasyonel, disiplinli ve öngörülebilir hale getirebilmek amacıyla kullanılır. İlk dönemine nazaran polis erki artık medenileştirici bir güç olarak ilerici bir misyon üstlenmiştir. Dahası yalnızca polis medenileştirici bir güç olarak görülmemiş her medenileştirici güç de polis erki kapsamında düşünülmüştür. Örneğin Almanya'da 17. yüzyılın sonlarında eğitim sistemi bir polis kurumu olarak görülüyordu. Temel amaç bireylerin kendi kendilerinin polisi olmasıydı (Dubber, 2005, s. 93). Bu bakımdan, Storch (1976)'un ortaya koyduğu şekliyle polis memurları, medenileştirici bir işlev üstlenerek "iç misyonerlere" dönüştü.

\section{"Yeni" Polis}

Londra Metropolitan Polisi'nin 1829'da kuruluşu geleneksel olarak modern polis teşkilatının başlangıcı olarak kabul edilir. Ancak bu bölümde ben bu polis biriminin 17. yüzyıl boyunca geliştirilen polis modelinin tahkimi olduğunu iddia edeceğim. Temel iddia, örgütsel-bürokratik çerçeve ile ilgili yenilikler dışında esas olarak modern polisin liberal toplumsal düzenin yerleşikleşmeye başladığı dönemde kazanmış olduğu imal edici işlevin devam ettiğidir. Bu bakımdan ana akım literatürde "yeni" olarak tanımlanan polisin aslında o kadar da yeni olmadığ ileri sürülecektir.

Geç 18. yüzyıl ve 19. yüzyılda Britanya İmparatorluğu dünyanın lider kapitalist ve endüstriyel gücüdür. Toplumsal formasyon aşamalı olarak kapitalistleşmektedir. Bu durum toplumsal düzenin çarpıcı bir şekilde dönüşümü ve düzensizlikle bağdaştırılan bir toplumsal atmosferin ortaya çımasını sağlar. Viyana Barışı'nı (1815) izleyen yıllarda "büyük çapta bir suç dalgasından" söz edilemese de (Taylor, 1997, s. 5) Britanya kentlerinde suç olaylarının yukarı doğru bir ivme gösterdiğini söylemek yanlış olmaz. Özellikle, 1820'lerde Londra halkı vahşet derecesinde kimi suçlara tanık olur (Bittner, 1973, s. 16). Hızlı kentleşme ve endüstrileşme yoğun bir göç dalgasına, yoksulluğa, ahlaki çöküntüye, suç ve toplumsal çatışmaya neden oldu (Reiner, 2000, s. 17). 1820'lerde, düzen ve düzensizlik gibi suç kavramının da anlamı değişmeye başladı.

Suç ve düzensizlik kavramlarının anlamlarının geç 18. yüzyıl ve erken 19. yüzyıl dolaylarında değişmeye başladığı söylenebilir. O tarihlerden itibaren suç ve suçlunun içinde bulunduğu sosyo-ekonomik koşullar arasında bir bağlantı kurulmaya başlanmıştı. Suç zamanla bireysel eylem olmaktan çıkarak toplumsal bir olguya dönüştü. Dahası bu dönemdeki kimi toplumsal 
eylemler hakim sınıfların "avam korkusunu" pekiştirdi. Örneğin 1780'deki Gordon İsyanları ve Napolyon Savaşları (1803-1815) ancak askeri güç yardımıyla kontrol altına alınabilen kent isyanlarına yol açıı (Bittner, 1973, s. 16). "1780 Haziranında merkez Londra mülkiyete hatırı sayılır bir oranda zarar veren, hapishanelere ve İngiltere Bankası'na, içlerinde yargıç ve sulh hâkimlerinin de bulunduğu kimi önde gelen figürlerin evlerine sembolik saldırılarda bulunan isyancı kalabalıkların eline geçmişti" (Taylor, 1997, s. 18). Bu kolektif eylemler, toplumsal hareketliliğin düzen için önemli bir tehdit olabileceği düşüncesini güçlendirdi. Bu bağlamda, toplumsal hareketlilik zamanla kriminalize edildi.

Söz konusu kriminalizasyonun bir veçhesini protestoların değişen anlamı oluşturur. Hobsbawm (aktaran Reiner, 2000, s. 24)'ın ifade ettiği gibi erken 19. yüzyıla kadar isyancı protestolar, politik olarak temsil edilmeyen kitlelerin dertlerini yönetici seçkinlere iletmek için kullandıkları araçlardı. "Fakat endüstriyel kapitalizmin yayılmasıyla isyan artık proto-demokrasinin bir formu olarak değil toplumsal ve politik düzene temel bir tehdit olarak görülmeye başlandı"(Reiner, 2000, s. 24). Kolektif eylemin anlamı da değişti: "Piyasa sisteminin ayaklanmalara karşı dayanıklılı̆̆ı, bildiğimiz bütün diğer sistemlerinkinden daha fazlaydı" (Polanyi, 2010, s. 259). Hakların korunması için ayaklanmak 18. yüzyıl boyunca kabul edilen meşru bir eylem biçimiydi. Thompson (aktaran Taylor, 1997, s. 17)' un da ifade ettiği gibi sonraları "y1kıcı" olarak kabul edildi. "Korkular büyüdükçe suça ve düzensizliğe karşı hoşgörü azaldı. Dahası, yeni davranış standartları, suça ve düzensizliğe karşı hoşgörüsüzlüğü artıran yeni beklentilere yol açtı" (Taylor, 1997, s. 13).

Thompson (1966; 1971; 1993)'ın önerdiği gibi kapitalist ilişkilerin gelişimi ve suçun değişen anlamı "göreneksel hakların" ve "geleneksel gösterilerin" meşruluğunun altını oymuştur. Kapitalizm-öncesi ekonomide, görenek hakları üretim sürecinin ve emekçilerin gündelik hayatlarının önemli bir parçasını oluşturmaktaydı. Emekçilerin çalışma koşullarındaki bir kötüleşme ya da refahlarındaki gerileme durumunda geleneksel gösteriler ve yiyecek ayaklanmaları memnuniyetsizliğin gösterilmesinin geleneksel araçlarıydı ve bu araçlar belirli bir dereceye kadar hukuki çerçeve içine de alınmıştı. Bu ayaklanmaların ve gösterilerin genel olarak reaksiyoner, kendiliğinden ve adhoc nitelikte olmalarına rağmen pratik politik sonuçları olabiliyordu. Thompson (1966, s. 63)'a göre ekmek ve/veya yiyecek isyanları 1840'lara kadar Britanya' nın hemen her kentinde yaygın bir şekilde görülüyordu. Bu ayaklanma ve gösteriler "ahlaki ekonomi" olarak adlandırılabilecek bir boyutun temel bileşenlerini oluşturuyordu. Thompson (1966, s. 63)'a göre, ahlaki ekonomi, 
"insanların ihtiyaçları üzerinden kar ederek geçimliklerin fiyatlarının adil olmayan artırılma yöntemlerinin ahlak dışılığını" kabul eder. Geç 18. yüzyıl ve 19. yüzyıl arasında ahlaki ekonomi yerini kademeli olarak kapitalist üretim ilişkilerine ve onunla birlikte yeni kültürel kalıplara, çalışma alışkanlıklarına, zaman ve disiplin algısına bırakır. Ekmek-merkezli kapitalizm-öncesi ekonomi kademeli olarak yerini nakit-merkezli piyasa ekonomisine terk eder. Geleneksel emekçiler ürettikleri ürün hakkında hiçbir şey talep edemeyen ücretli emek haline gelirler. $\mathrm{Bu}$, ahlaki ekonominin, geleneksel adalet kavramsallaştırmasına tabi olan fiyatların ve ilişkilerin, arz ve talebin gayri-şahsi yasalarıyla yönetilen saf pazar ekonomisi ile ikame edildiği daha geniş bir değişimdir (Thompson, 1966; 1971; 1991).

Liberalizm adına bazı formel-legal hakların ve sözleşme özgürlügünün tanınması ile birlikte norm dışı davranışa karşı hoşgörüsüzlük oranı arttı. Formel-legal hakları kısıtlayan fakat geniş bir yelpazede görenek ve davranışları hoş gören liberal-öncesi dönemin düzen anlayışına karşıt olarak, liberal zihniyet suça karşı daha güçlü bir hassasiyet geliştirdi. Artık suç “Kent nüfusunun zengin ve efendisiz ve iş bulamayan fakir arasında giderek daha fazla bölündüğü... kriz içindeki bir toplumun semptomu" olarak görülmeye başlandı (Smith, 1985, ss. 18-19).

Manifaktür ve fabrikalarda yerleşikleşen yeni çalışma disiplini formellegal olarak özgür işçilere ihtiyaç duydu. Ancak bu, işçilerin üretim sürecinde ve hatta boş zamanlarında daha sıkı bir disipline tabi olmaları anlamına geldi. Cohen (aktaran Reiner, 2000, s. 25)'in belirttiği gibi böylece sokaklardaki geleneksel zaman geçirme biçimleri kriminalize edildi. Köpek dövüştürme, içki içme, at yarışları gibi aktiviteler toplumsal düzen için birer tehdit olarak algılanmaya başlandı (Coleman \& McCahill, 2011, s. 60). Cohen (aktaran Reiner, 2000, s. 25)'in dikkat çektiği gibi polis memuru kamu adab-1 muaşeretinin ahlaki timsali olmaya başladı. Polis, sokaktaki vahşi ve geleneksel davranış kalıplarını nezaket ve saygı çerçevesinde dönüştürme görevini üstlendi (Reiner, 2000, s. 25).

"Yeni" polis ile birlikte ayrıca önleme fikri tahkim edildi. Yeni polis teşkilatının kurucuları ve entelektüelleri olarak Sir Robert Peel (1788-1850) ve Patrick Colquhoun (1745-1820) yeni polis gücünün görevinin suçları tespit etmekten çok onları önlemek olduğunu vurguladılar. Önleme fikri suçun kendisinin bireysel-psikolojik değil ve fakat toplumsal bir olgu olduğunu önvarsaymaktaydı. Söz konusu olan artık sosyo-ekonomik olarak dezavantajlı grupların düzenli takip ve kontrolünden daha çok ve daha büyük 
oranda, yaygın uygunsuz davranışları baskılayacak yeni davranış kalıplarının teşviki ve üretilmesi oldu. Öyleyse, altı çizilmesi gereken, önleme fikrinin burjuva düzeninin kademeli imali ile uyum içinde olmasıdır. Önleme, palyatif ya da ad hoc çözümlerdense sistematik bir çözüm imasında bulunur. Polisin temel misyonu suçluları yakalamaktan çok bazı davranışları teşvik edip diğerlerini caydıracak bir toplumsal çerçeveye katkıda bulunmaktır. O halde, bireysel olarak suçludan toplumsal bir çerçeve olarak suç kavramsallaştırmasına geçiş vardır. Dahası, önleme fikri, liberal toplumsal düzenin tahkimi yoluyla düzensizliğin ortadan kalkacağını öne süren ilerlemeci ve iyimser liberal varsayımlarla da bağdaşmaktadır.

Yaygın kanının aksine "tehlikeli sınıflardan" söz edildiğini duyabilmemiz için 1840'ları beklememiz gerekmektedir (Smith, 1985, s. 17). Bu tespit, bu çalışmada öne sürülen modern polis teşkilatının ortaya çıkmasının "tehlikeli" ya da "suçlu" sınıflara karşı doğrudan bir cevap olmadığı şeklindeki argümanı güçlendirmektedir. Polis gücü, daha ziyade merkezinde ücretli emek olarak işçi sınıfının temel bir rol oynadığı liberal toplumsal düzenin imalinde kullanılan zorlayıcı ve üretici bir güçtür. İşçi sınıfı burjuva toplumuna içkin olduğu için devlet erkinin bir formu olarak polis erki işçi sınıfının oluşumunda rol almıştır (Neocleous, 1996, 2000).

Marx (2011)'n Kapital'de öne sürdüğü gibi feodal üretim tarzından kapitalist üretim tarzına geçiş, küçük köylülüğün mülksüzleşerek ücretli emeğe dönüşmesi sayesinde mümkün oldu. Dolaysız üretici, feodal çalışma ilişkilerinin tedrici çöküşü ile birlikte feodal üretim araçlarından koptu ve iki anlamda "özgür" hale geldi: Feodal lorddan ve üretim araçlarından "özgürlük". Bu gelişmeler kapitalist üretim tarzının ayırt edici özellikleri haline geldi. Emek, formel-legal olarak özgürleşti. Ancak bu özgürlük öbür taraftan zaman zaman "aylaklığa" dönüştü. Buradan hareketle, polislik faaliyetinin bir başka boyutunun da yoksullara "iş dayatma" olduğu söylenebilir (Neocleous, 2000, ss. 11-21). Aşağıda işçi sınıfının "ataları" olan "efendisizlerin" kentte yarattıkları güvenlik sorununa bir çözüm olarak polis projesi aracıllğıyla işçi sınıfına dönüştürülmesi gerektiğini savunan iki İskoç düşünür Patrick Calquhoun (1745-1820) ve Adam Smith (1723- 1790) ele alacaktır.

\section{"Efendisizler"den Polis Aracılığıyla İşçi Sınıfına: Patrick Colquhoun ve Adam Smith}

İskoç bir tüccar, istatistikçi, magistrate [sulh hakimi] ve İngiltere' deki ilk düzenli polis gücünün kurucusu olan Patrick Colquhoun (1745-1820) Treatise 
on Indigence [Sefalet Üzerine İnceleme] (1806) kitabında "iş dayatmayı" açık bir şekilde polis projesine bağlar. Colquhoun, ilk olarak yoksulluk ve sefalet arasında bir ayrım yapar. Yoksulluk sermaye ve ücretli emek yokluğunun doğal bir sonucu iken sefalet insanların, fiziki ve zihinsel hastalık, sarhoşluk, aylaklık, kötü niyetlilik gibi sebeplerden çalışmaması ya da çalışamaması durumundan ileri gelmektedir. Bu anlamda, "musibet" yoksulluk değil ve fakat sefalet kaynaklıdır. Yoksulluk ise yokluğunda emek gücünün var olamayacağı "refahın ve zenginliğin kaynağıdır". Yoksul aşağı yukarı işçi sınıfı için kullanılan eş anlamlı bir sözcük iken sefil lümpen proletaryaya yakın bir anlama sahiptir. Emek gücü sorunu doğrudan toplumsal düzen sorununa bağlıdır. Colquhoun için düzen ve suç sorunu birbiriyle ilişkili iki yol izlenerek çözülebilir; ilk olarak içinde yoksulluğun ve ücretli emeğin güvence altına alındığı bir sistem kurmak ve ikinci olarak birikim sürecinde hiçbir işe yaramayan sefil insanlara iş dayatmak. O halde, Colquhoun için polislik faaliyetinin önemli ayaklarından birinin lümpen proletaryanın proletaryaya dönüştürülmesi olduğu söylenebilir. Benzer şekilde Colquhoun'un çözümü emek gücünden başka satacak şeyi olmayanların "kötü alışkanlıklarından" arındırılarak ücretli emek sistemine dahil edilmesidir. Colquhoun(1806, s. 82)'a göre "polis terimi ile ister sefalet belası olsun, isterse de ahlaki ya da suça ait taarruzların ürettiği etkiler bakımından olsun, bir ülkedeki sakinlerin konforu, rahatlığı ve emniyetini ilgilendiren tüm düzenlemeleri anlıyoruz." Colquhoun ayrıca polis projesinin tamamlayıcıları olarak işçi sınıfı çocuklarının eğitimini ve "çalışma evlerinin" koşullarının iyileştirilmesi gerektiğini ifade eder. Polis erkinin ekonomi-politiği ile ilgili olarak yukarıda dile getirilenler de dikkate alınarak polis erkinin, feodal üreticilerin kapitalist üretim ilişkileri içinde ücretli emeğe dönüşümlerinde önemli bir rol oynadığı söylenebilir.

İskoç Aydınlanması' nın önemli figürlerinden Adam Smith (1723-1790), ahlak felsefesi alanında da önemli eserler vermekle birlikte esas olarak ekonomi-politik üzerine düşünceleri ve çalışmalarıyla bilinir. Feodalizmin tedrici çözülüşü ve kapitalizmin aşamalı bir şekilde yerleşikleştiği tarihsel kavşakta Smith; devlet, polis, piyasa ve toplumsal düzen'in imali hakkında önemli fikirler ileri sürmüştür. Aşağıda özellikle ekonomi-politik alanında ileri sürmüş olduğu düşüncelerinin bulunduğu kitap olan opus magnumu Ulusların Zenginliği'nin [The Wealth of Nations] (1776) gölgesinde kalan; ancak özellikle liberal toplumsal düzenin inşası ve polis erki hakkında önemli ipuçları içeren İçtihat Üzerine Dersler [Lectures on Jurisprudence] kitabı üzerinde durulacaktır. 
İçtihat Üzerine Dersler Smith'in Glasgow Üniversitesi'nde 1762-1763 ve 1763-1764 yılında vermiş olduğu derslerin iki farklı katılımcı tarafından alınmış notlarından oluşmaktadır. Derslerde ortaya konan fikirler daha sonra Smith'in en etkili kitabı olan Uluslarm Zenginliği'nin ana materyalini oluşturacaktır. Smith verdiği dersler boyunca içtihadın kısmen iki farklı tanımını ortaya koymuştur. Bunlardan birincisi sivil hükümetin yönetilmesi için gerekli olan kurallar bütünüdür (A. Smith, 1982, s. 5). İkicisine göre ise içtihad tüm ulusların yasalarının dayanakları olması gereken ilkeleri araştıran bir bilimdir (A. Smith, 1982, s. 397). İçtihat, dört öğeden oluşur 1-) Mülkiyetin güvenliği (adalet) 2-) Polis 3-) Gelir 4-) Silahlar. Bu dört öğenin her hükümet tarafından dikkatlice ele alınması gerekmektedir. Bu çalışmada hükümetin ikinci görevi en genel anlamda "devletin refahını artırmak anlamına gelen" polis erki üzerinde durulmakla yetinilecektir. Bir ülkede ticaret, tarım ve manifaktür ile ilgili tüm düzenlemeler polis adını alır. Smith (1982, s. 5)' e göre polis'in üç işlevi vardır: 1-) temizlik [netteté] 2-) huzur ya da güvenlik [aisance] 3-) geçimliklerin ucuz olması [bon marché].

Birinci işlev ile ilgili altı çizilmesi gereken husus 17. ve 18. yüzyıl itibariyle temizlik ile salgın hastalıklar arasındaki bağlantı kurulmaya başlanmış olduğundan temizliğin bir hükümet sorunu haline gelmiş olmasıdır. Polisin en önemli görevlerinden biri yolların ve caddelerin temizliğinin sağlanmasıdır. Yukarıda değinildiği gibi feodalizmin kademeli çözülüşü kırdan kente göç eden nüfusun sayısını artırdı. Dolayısıyla 18. yüzyıl boyunca kentlerdeki yoksul kitleler salgın hastalıkların sorumlusu olarak görüldü. $\mathrm{Bu}$ nedenle kentlerin temizliğinden sorumlu örgütlü bir güce ihtiyaç duyuldu. Polis işte bu işlevi üstlendi. Yoksul, adeta varlıklı sinıfların biyo-politik düşmanı olarak görüldü ve temizlik, sağlık ve medeniyet arasında bir bağ kurulmaya başlandı. Polis bu denklemde kilit bir rol oynadı.

Polisin ikinci işlevi ikiye ayrılabilir. Birincisi yangınlar ve buna benzer kazalar ile ilgili iken ikincisi polisin bugün bildiğimiz anlamına yakın olarak suçların önlenmesi ve suçluların yakalanması ile ilgili vazifesidir. Smith bu işlevi "polis adaleti" olarak betimler. Bu noktada Smith hayati öneme sahip bir tespit yapmaktadır. Smith, Hume'un tarihini ${ }^{5}$ izleyerek İngiltere' de -ve aynı dönemde Fransa' da da- Kraliçe Elizabeth (1533-1603) dönemindeki genel düzensizliğin nedeninin feodalizmin çözülüşü olduğunu savlar. Soylu efendilerinden kopan "aylaklar" hayatlarını kazanabilecek

\footnotetext{
5 İngiliz ampirisist filozof David Hume, felsefi eserleri dışında 1754-1762 yılları arasında altı ciltlik Ingiltere Tarihi'ni yayınladı. Smith'in değerlendirmelerine kaynak olan bu eserdir.
} 
araçlardan yoksun oldukları için soygun, yağma ve talan olaylarına karışarak büyük bir düzensizliğe neden oldular (A. Smith, 1982, s. 486). Smith, o dönemde Krallıkta işlenen cinayet sayısının önceki dönemlere nazaran çok daha yüksek olduğunu ifade eder. Efendilerinden kopan bu uşaklar "efendisizler" [Masterless Men] olarak suçun ve kötülüğün esas kaynağını oluşturmuştur. Argümanın kanıtlamak için Smith bir örnek verir. Glasgow'da efendilerin genellikle tek bir uşağ 1 varken Edinburgh'ta birden fazla uşağa sahip olmak yaygındır. Buna bağlı olarak Glasgow'daki büyük nitelikteki suçların sayısı düşükken Edinburgh'ta bu sayı oldukça fazladır (A. Smith, 1982, ss. 486-487). O halde sorun efendisiz kalan uşaklar üzerinde otorite tesis etme sorunudur. Bu noktada Smith'in çözümü etkileyicidir: efendisize yeni efendi olarak sermayeyi sunar (Neocleous, 2000, s. 65). Smith (1982, ss. 333-486-487)'e göre:

“...Ticaret bu göreneğin büyük bir önleyicisidir... Bu özerkliği getiren ticaretin ve manifaktürlerin kurulması suçların önlenmesinde en iyi polistir... Manifaktürler, yoksula herhangi bir efendinin karşllayabileceğinden daha yüksek maaş verir; ayrıca zengine asla sahip olmakta başarısız olmayacağı servetini daha az uşakla harcama imkânı verir." (italik bana ait)

Son olarak polisin üçüncü işlevi geçimlik arzını ve ucuzluğunu güvence altına almaktır. Smith polisin açık bir şekilde piyasaya müdahale etmesi gerektiğini savunmaktadır. Bu piyasanın kendi kendini düzenleyen ve oluşturan bir mekanizma olmadığı anlamına gelir. Uluslarm Zenginliği'nde "görünmez ele" bırakılacak piyasayı düzenleme görevi polisin görünen eline teslim edilmiştir.

Böylece gerek Colquhoun gerekse de Smith, kapitalist toplumsallaşmayı ön gören liberal entelektüel projenin organik aydınları rolünü oynadılar. Bu isimler, liberal ajandaları uyarınca polis erkine reaktif değil; proaktif bir rol biçtiler. Kent güvenliğinin sağlanması için polis erkinin suçluları yakalamaktan fazlasını yaparak, suçun ortaya çıkmasını önleyecek bir toplumsal ekosistem yaratılmasında, efendisizlerin, yoksulların, suçluların ücretli emeğe dönüştürülmesinde kullanılması gerektiğini savundular. Ezcümle, polis erki yoksulluğun yönetiminde ve "efendisizlerin" işçi sınıfına dönüşümünde belirleyici güç haline geldi.

\section{Sonuç Yerine}

Bu çalışma kent ve güvenlik arasındaki ilişkiyi polis kavramı üzerinden ele almayı önermiş ve özel olarak feodalizmden kapitalizme geçiş dönemine 
odaklanmıştır. Çalışma bugün kullandığımız polis kavramının Antik Yunan kent devleti polis'ten geldiğini hatırlatarak tarihsel ve etimolojik bağlantıları göstermeyi amaçlamıştır. Roma Dönemi'nde polisin görevi halen bir bütün olarak polis'in yönetilmesi ile ilgilidir. Roma İmparatorluğu'nun çöküşü ile unutulan kavram 15. ve 16. yüzyıllardan itibaren Avrupa'da yeniden ortaya çıkmış ve esas olarak feodal toplumsal düzenin statik yapısının korunması ile ilgili olmuştur. Feodal ilişkilerin çözülmesi sonucu kırdan kente akın eden kitleler kent güvenliğini tehdit ederek polisin işlevinin yeniden tanımlanmasına neden olmuştur. Modern bilimin ve kapitalist üretim ilişkilerinin gelişmesiyle birlikte 17 . ve 18. yüzyıllarda polis, devletin burjuva sivil toplumu dönüştürme mekanizmalarının en önemlilerinden biri haline gelmiştir. Polis, kentlerde kümelenen ve suç olarak görülmeye başlanan davranış kalıplarını yükselen burjuva değerleri doğrultusunda dönüştürme vazifesini üstlenmiştir. Bu dönemde polisin esas işlevi Colquhoun ve Smith'in formülasyonuna göre "efendisizlerin" ücretli emeğe dönüştürülerek sermayeye ve onu mümkün kılan toplumsal düzene tabi kılmaktır. Burada dikkat çekilmesi gereken husus özellikle önleme fikrinin de gelişmesiyle kent güvenliğinin tikel suçluların yakalanmasından çok ortaya çıkmakta olan burjuva sivil toplum düzeninin inşası ile ilgili olduğu düşüncesidir. Aylaklık ve suç ile özdeşleştirilen tabi sınıflar sermayenin denetiminde polis erki aracılığıyla işçi sınıfına dönüştürülmektedir. Kent güvenliğini sağlamanın en iyi yolu suçluyu yakalamak değil suçluyu belirli bir toplumsal düzen uyarınca dönüştürmektir.

Her ne kadar bu çalışma polis erkinin değişen rolünü esas olarak feodalizmden kapitalizme geçiş bağlamında ele almış olsa da metne ait kimi teorik içerimler bugünün dünyasını anlamak için de kullanılabilir. Bu teorik süreklilik şöyle ortaya konabilir: Birincisi, polis erki, amacı suçluları adalete teslim etmek olan bir kurumdan ziyade devlet erkinin bir formu, toplumsal çerçeveyi imal eden bir sosyo-politik güç olarak görülmelidir. İkincisi, polis erkinin güvenliğin sağlanmasındaki rolü teknik, mesleki ya da doğal olmaktan ziyade tarihi, stratejik ve politiktir. Üçüncüsü, polis kent güvenliğini kente dair bir hegemonik vizyona, kentin nasıl olması gerektiğine dair bir tahayyüle göre yapılandırır. Daha somutlaştırmak gerekirse 1980'lerle birlikte kapitalizmin Keynesçi modelinden neo-liberal varyantına geçiş s1rasında, polis erkinin toplumsal hareketliliğin bastırılmasında, yoksulluğun yönetilmesinde, kentsel dönüşüme uğrayan mahallelerde tepkilerin etkisizleştirilmesinde aktif olarak kullanıldığı söylenebilir. Bir neo-liberal pratik olarak mutenalaştırma ile ilgili şöyle bir örnek verilebilir. Mutenalaştırma, 
devlet erkinin belirli bir sosyo-politik proje (neo-liberalizm) uyarınca kentsel mekâna (ya da daha soyut düzeyde burjuva-sivil topluma) polis erki aracılığıyla müdahale etmesi şeklinde okunabilir. Burada polisin devlet erkinin burjuva-sivil topluma müdahale kapasitesi olarak değerlendirildiğinin altı çizilmelidir. Polis erki ne salt suçluları yakalamakta ne de toplumsal hareketliliği bastırmakta; daha ziyade neo-liberal toplumsal düzeni ve neoliberal kenti yaratmaktadır. Dolayısıyla polisin yaratıcı rolünün feodalizmden kapitalizme geçiş dönemine özgü olmadığı, başka tarihsel bağlamlarda da devam ettiği belirtilebilir. Dördüncüsü, tüm bu söylenenler, kent güvenliğinin ve polis meselesinin, suçu toplumsal davranış örüntülerinin dışına sapma olarak nitelendiren kriminoloji ya da sosyol kontrol teorilerinin ötesinde sosyo-politik bir mesele olarak yeniden alımlanması gerektiğini ortaya koymaktadır. Uyuşturucu, hırsızlık, dilencilik vb. suçlar bireysel-atomistik olarak değil de toplumsal bağlamı içinde anlaşılmalı, toplumsal düzen ile suç arasında karşılıklı ilişki kurulmalıdır. Polis erki bu ilişki içinde merkezi bir rol oynar. Beşincisi, böylesi bir yaklaşım kent güvenliği bakımindan polisin kendisinden çok içinde eylediği sosyo-politik ve stratejik bağlamlara odaklanmayı, polis eylemliliğini bu çerçeveler içinden türeterek anlamlandırmayı önermektedir. Bu önerme polis eylemliliğini stratejik dönemselleştirmeler içinde ele almak gerektiği anlamına gelmektedir. Feodalizmden kapitalizme geçiş, laissez-faireci kapitalizm, Keynesçi kapitalizm ya da neo-liberal kapitalizm gibi tarihsel bağlamlar içinde kent güvenliği ile ilgili tahayyüller ve polis pratikleri ilişkilendirilmelidir. Başka bir ifade ile hem kent güvenliği mefhumunun kendisi hem de polis hareketliliği farklı stratejik bağlamlarda, farklı iktidar ilişkileri kombinasyonları içinde ele alınmalıdır. Kent güvenliği kavramı farklı hegemonik tahayyüller içinde politik olarak kurulduğundan farklı bir kent güvenliği mefhumu ancak karşı hegemonik tahayyüller içinden oluşturulabilir. Bu önermelerden şu genel sonuç çıkarılabilir: Kent güvenliği, dar anlamda kentin ve daha geniş anlamda toplumsal düzenin nasıl olması gerektiği ile ilgili ortaya konulan sosyo-politik proje(ler) ile sıkı sıkıya bağlıdır. Kent güvenliği ile ilgili sonraki çalışmalar bu ikisi arasındaki ampirik eklemlenme biçimlerine odaklanmalıdır. 


\title{
Extended Abstract
}

\section{At the Down of Capitalism: City, Police and Security}

*

\author{
Erol Subaşı \\ Recep Tayyip Erdoğan University
}

There is a growing body of literature that recognises the importance of the concept of security. Especially, after the collapse of the Soviet Union and the 9/11 attacks security has become to be understood as the dominant parameter shaping both internal and external power relations. In fact, for a while now, the security studies have emerged as a sub-discipline of International Relations. Even the very existence of such an academic discipline indicates the ever-increasing importance of the concept of security.

Another significant phenomenon is urbanisation. Even though cities have existed for thousands of years, only recently for the first time in history, the number of the people living in urban areas is more than the ones living in rural areas. This has made the cities even more critical topic regarding security concerns.

While the security of the cities and the police has been a question of great interest in various disciplines, very little attention has been paid to the constitutive role of police in the security of the city. Traditionally, police were treated either as an institution or an instrument. The former, liberal approach, reduced police power to the institution of police and defined it by its function of law enforcement. The latter, orthodox -Marxist one, regarded it solely as a repressive apparatus of the state whose primary purpose is suppressing the politicisation of the working class.

The approach taken here, differing from both, suggests that the function of the police power as a form of state power is neither limited to law enforcement nor the oppression of political mobilization of the working class; instead, as a socio-political power, it is to fabricate the social order according to specific social, behavioural patterns. In this re- 
gard, the primary aim of this paper is to show the links between city, police, security and social order. The central question in this paper is the following: How the police power provides the security of the city? The method adopted here consists of re-historicising and re-politicising of the concept of police and re-reading of canonical texts.

The study has been organized in the following way: The first section gives a brief overview of the etymological connections between polis, policy and police. The modern concept of police and policy directly comes from the Latin word politia meaning civil administration which itself derives from the word Ancient Greek City-State polis. The decline of Roman Empire led to the disappearance of the concept. Only as late as in the 15th century, the idea of police reappeared in France. Soon after, the idea and as well as institution of police spread to Germany, Spain and Italy.

The second section reveals the changing role of the police power. The police as reappeared in the 15th century France had a function, as consistent with feudalism, to keep things in their pre-given places. However, as the idea of change and progress, colonises the Western mind due to Scientific Revolution and Enlightenment, the concept of police began to be associated with this obsession with development and improvement. In turn, the idea of order itself began to change, and it became to be understood as something profane and changeable. Hence, if social order is unstable, then, the political power, particularly the state power, could be used to (re)shape it. Therefore, in this context, the police power as a part of state power became operational in that sense.

Third section deals with the modern foundation of the "new police". The main concern is to show the continuity and discontinuity between "old" and "new" understandings of the police. The section underlines that it is difficult to identify significant differences between the old and new ones except for organizational and institutional features. Furthermore, it is discussed that with the development of the idea of prevention, the new police, compared to the old one, even more, engaged in the fabrication of the new bourgeois social order.

The fourth section is devoted to displaying the productive aspect of police power through a re-reading of Patrick Colquhoun and Adam Smith. Patrick Colquhoun, as the founder of the modern police force in Britain, developed a political economic approach to the police power. He explicitly linked his police project to the problem of poverty that he considered as a necessary condition of labour power. Thus, he proposed to impose work on the poor using police power. Therefore, police power 
seemed to be envisioned as useful especially in transforming the poor into the working class. Similarly, being famous for his account of political economy, Adam Smith expressed key ideas on this ground. He argued that the fall of feudalism was the main reason behind the increase in the urban population. The "masterless men" freed from their feudal ties, migrated to the cities. This unparalleled population growth brought anonymity and posed a threat to the security of the city. Hence, Smith proposed a solution according to which with the help of the police power, these "masterless men" should be subjugated to the system of manufactures. In other words, Smith reintroduced a new master to the "masterless men": the manufacturer.

The study deliberately concentrates on a particular historical era to reveal the links between police power and the security of the city. Its primary goal is to provide a historical and political understanding of the police power to grasp better the relationship between city, security and the social order. Even though the study does not directly and empirically refer to today's world, its theoretical framework still allows us for an explanation of how current security issues might be captured. To this end, further studies should also demonstrate contemporary empirical articulations between city, police and security.

\section{Kaynakça/References}

Bittner, E. (1973). The functions of the police in modern society. Maryland: National Institute of Mental Health, Center for Studies of Crime and Delinquency.

Chapman, B. (1970). Police State. London: Pall Mall Press.

Coleman, R., \& McCahill, M. (2011). Surveillance and crime. London: Sage.

Colquhoun, P. (1806). A treatise on indigence, etc. London: J. Hatchard.

Dubber, M. D. (2005). The police power: Patriarchy and the Foundations of American Government. New York: Columbia University Press.

Hobbes, T. (1996). Leviathan (R. Tuck, Ed.). Cambridge: Cambridge University Press.

Marx, K. (2011). Kapital I.Cilt. (M. Selik \& N. Satligan, Çev.). İstanbul: Yordam Kitap.

Neocleous, M. (2000). The fabrication of social order: A critical theory of police power. London: Pluto Press.

Polanyi, K. (2010). Büyük dönüşüm çağımızın siyasal ve ekonomik kökenleri. (A. Buğra, Çev.) (9. baskı). İstanbul: İletişim Yayınları.

Raeff, M. (1983). The well-ordered police state: Social and institutional change through law in the Germanies and Russia, 1600-1800. New Haven: Yale Univ Pr. 
Reiner, R. (2000). The politics of the police (3. bask1). New York: OUP Oxford.

Rigakos, G. S., McMullan, J. L., Johnson, J., \& Özcan, G. (Ed.). (2009). A general police system: Political economy and security in the age of enlightenment. Ottawa: Red Quill Books.

Smith, A. (1982). Lectures on jurisprudence. (R. L. Meek, D. D. Raphael, \& P. G. Stein, Ed.). Indianapolis: Liberty Fund.

Smith, P. T. (1985). Policing victorian London: Political policing, public order, and the London metropolitan police. Westport, Conn: Greenwood Press.

Storch, R. D. (1976). The policeman as domestic missionary: Urban discipline and popular culture in Northern England, 1850-1880. Journal of Social History, 9(4), 481-509.

Taylor, D. (1997). The new police in nineteenth-century England: Crime, conflict and control. Manchester: Manchester University Press.

Thompson, E. P. (1966). The making of the English working class. New York: Vintage.

Thompson, E. P. (1971). The moral economy of the English crowd in the eighteenth century. Past and present, (50), 76-136.

Thompson, E. P. (1993). Customs in common. London: Penguin Books.

Tilly, C. (1992). Coercion, capital and European States: AD 990 - 1992 (Revised edition). Cambridge, MA: Wiley-Blackwell.

Arş. Gör. Dr. Erol Subaşi: 2008 yılında Marmara Üniversitesi Fransızca Kamu Yönetimi Bölümü'nü bitirdi. 2011 Yılında Galatasaray Üniversitesi Siyaset Bilimi Yüksek Lisans Programı'ndan yüksek lisans derecesini yine aynı bölümde 2018 yılında Doktora derecesini aldı. Subaşi, halen Recep Tayyip Erdoğan Üniversitesi Siyaset Bilimi ve Kamu Yönetimi Bölümü'nde Araştırma Görevlisi Dr. olarak görev yapmaktadır. Araştırma alanları devlet teorisi, güvenlik, toplumsal düzen, askeri darbeler, militarizm, polis teorisi ve ekonomi politik gibi konuları kapsamaktadır.

Research Assistant Dr Erol Subasi: Subasi graduated from the Department of Public Administration (French), Marmara University in 2008. He later received his master's degree in 2011 and PhD in 2018 from the Department of Political Science in Galatasaray University. He currently works as a Research Assistant Dr at Recep Tayyip Erdogan University. His research interests include state theory, security, social order, military coups, militarism, police theory and political economy.

E-mail: erol.subasi@erdogan.edu.tr

\section{Kaynakça Bilgisi / Citation Information}

Subasi, E. (2018). Kapitalizmin şafağında: Kent, polis ve güvenlik. IDEALKENT - Kent Araştırmaları Dergisi, 23, 113-133. 